\title{
河川空間の記号化表現による形態的特性とシークエンス構成の分析 ANALYSIS OF THE MORPHOLOGICAL CHARACTERISTIC AND SEQUENCE CONSTITUTION BY THE SEMIOTICS EXPRESSION OF THE RIVER SPACE
}

\author{
積田 洋*, 鈴木規 道**, 津 村 佳 余*** \\ Hiroshi TSUMITA, Norimichi SUZUKI and Kayo TSUMURA
}

\begin{abstract}
The role of the river which has an exaggerated space in city development is an important element showing regionality. Attractive planning of River Space is important thing for raise the identity of the city and city life with the amenity. In this study (1) Target at various river space from High-profile international city. (2) To devise expression in semiotic of the morphological characteristics in river space. (3) Shows the Model at composition of each river space and performed the analysis and classification. (4) Analysis of the morphological characteristic and sequence constitution and showed the changing point of the space. (5) Showing the morphological characteristics of each target to extract the patterns and their patterns of occurrence for each element.
\end{abstract}

\footnotetext{
Keywords :River Space, Composition Elements, Urban Semiotics,

Morphological characteristic, Changing point of the space

河川空間, 構成要素, 記号化表現, 形態的特性, 変化点
}

\section{1. 研究背景・目的}

都市に扔いて河川の持つ役割は、その都市の地域性を表象する重 要な位置づけであると言っても過言ではない。例えばパリではセー ヌ川の中州であるシテ島を中心に発展を見せた事例がある。シテ島 に位置するノートルダム大聖堂をはじめとし、河川沿いに点在する ランドマークや歴史的建造群が多く存在し都市の骨格を形成してい る。またロンドン・テムズ川やローマ・テヴェレ川など大都市にお いても同様に河川沿いに歴史的建造物やランドマークが計画される など都市形成において重要な役割を持ち、都市の顔の一部となって いる。それらに見られるように魅力的な河川空間の計画は、その都 市のアイデンティティを高め都市の表象として、都市景観やアメニ ティのある場として重要なものである。

すでに筆者らは既報 ${ }^{1)}$ で河川空間の護岸断面形状と構成要素に着 目し、《意識型》 注 1) 《形態型》 注2) のマトリクス分析から心理評価の 傾向を具体的な空間の作られ方と対応させて関係を数理的に明らか にし、計画の手がかりを示した。しかし既報では対象が比較的小規 模なもので、日本国内に限定されていたこと、具体的な構成や護岸 断面形状が心理に及ぼす影響を考察することを主眼としていたため 都市スケールから見た河川空間の形態的特徴を明らかにする点に余 地を残していた。そこで本研究では、各都市の河川空間の構成と
その特徴を端的に表すために、(1)対象地を国際的な知名度のある都 市を対象とし選定を行う。(2選定された対象の構成要素を統一的に 分解し、共通の言葉として扱うことのできる形態的特徵の記号化表 現により客観的に示す手法を考案する。(3) (2)の手法を用いて各河 川ごとの構成モデルを示し、対象ごとの分析および類型化を行う。 さらに(4)各要素ごとに川上から川下に沿ったシークエンシャルな構 成と見なし、その変化を詳細に分析し、変化点を示し分析を行う。 最後に(5)各構成要素ごとの出現型を抽出し各対象の形態的特徴を示 す。これらの方法を用いて質的条件の異なる河川空間の構成比較に おいて一定の条件を設けた記号化表現を用いることで複雑に構成さ れている河川空間の形態的特徴を総体として表し、要素ごとの出現 型を示すことで各河川の空間構造を見出す事を目的としている。

なお本研究に関する既往研究として畔柳らの親水空間における行

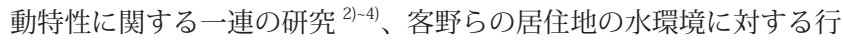
動・認識扔よびその連関に関する研究 ${ }^{5)}$ 、村川・西名らのコンピュー ター画像処理、住民評価などによる河川環境評価手法に関する一連 の研究 ${ }^{6) \sim 10)}$ がある。さらに記号化表現として門内らによる街並みの 景観に関する記号学的研究 ${ }^{11)}$ があり、日本の伝統的な街並みに共有 された街並みのコードを作成しそれらに基づきタウンテクスチュア の形態的構造の分析を行い、多義的なテクストとして解読し街並み
* 東京電機大学未来科学部建築学科 教授 ·博士 (工学)

** 東京電機大学大学院先端科学技術研究科 建築・建設環境工学専攻 博士後期課程

*** 東京電機大学大学院未来科学研究科建築学専攻 修士課程
Prof., Dept. of Architecture, School of Science and Technology for Future, TDU, Dr. Eng. Graduate Student, Dept. of Architecture, Civil and Environmental Engineering, TDU, M. Eng.

Graduate School of Science and Technology for Future, Tokyo Denki Univ. 
における記号現象の仕組みを「街並み記号論」と して明らかにしている。さらにシークエンスの研 究として参道空間の構成の変化を分節点 ${ }^{\text {注 } 3)}$ とし て、心理的な変化との関係を明らかにした筆者ら の参道空間の分節と空間構成要素の分析 ${ }^{12)}$ があ る。本研究は対象を大都市を流れる河川沿いの空 間とし、記号化表現として河川構成図の考案、変 化点及び出現型を明らかにしそれらを基に形態的 特徴を示すものであり、次編で予定している心理 的影響も含めて河川空間の構造を明らかにするも のであり、目的を異にしている。

\section{2. 対象地区選定}

対象地区選定にあたっては、主に都市名の国 際的な知名度が高く、数百万人規模の人口がある 大都市を GaWC (Globalization and World Cities Study Group and Network）が定めた主要な世界 都市注 ${ }^{4)}$ 第 1-3 級世界都市」をガイドラインとし、 Google-Earth の衛星写真より建物間口、歩車道、 水面幅の寸法が把握可能かつ、ストリートビュー 機能により河川沿いを仮想的に歩く事ができ連続 立面図の作成が可能である 8 都市 12 箇所を選定 した(図1)。【】カッコ内は各都市の略称を示す。

\section{3. 研究方法}

対象の区間を各都市統一的に扱うため主要中心 部、前後約 $3500 \mathrm{~m}$ に統一し、河川空間を構成す る基本的な要素として以下の 6 要素、【A. 水面幅】 【B. 護岸形状】【C. 歩車道・公園】【D. 緑】【E. 建 物高さ】【F. 棟数密度】を検討の上、採用した (図 2)。Google-Earth の航空写真より対象区間の河川 沿いの建物平面・歩車道・公園の形状を C A D ${ }^{\text {注5) }}$ を用いトレースを行いそれらを基に水面の幅・棟 数密度を算出した。建物高さ・緑量においては立 面写真より算出した。各要素ごとの詳細な算出方 法は注6) に示す。また【B. 護岸形状】においては、

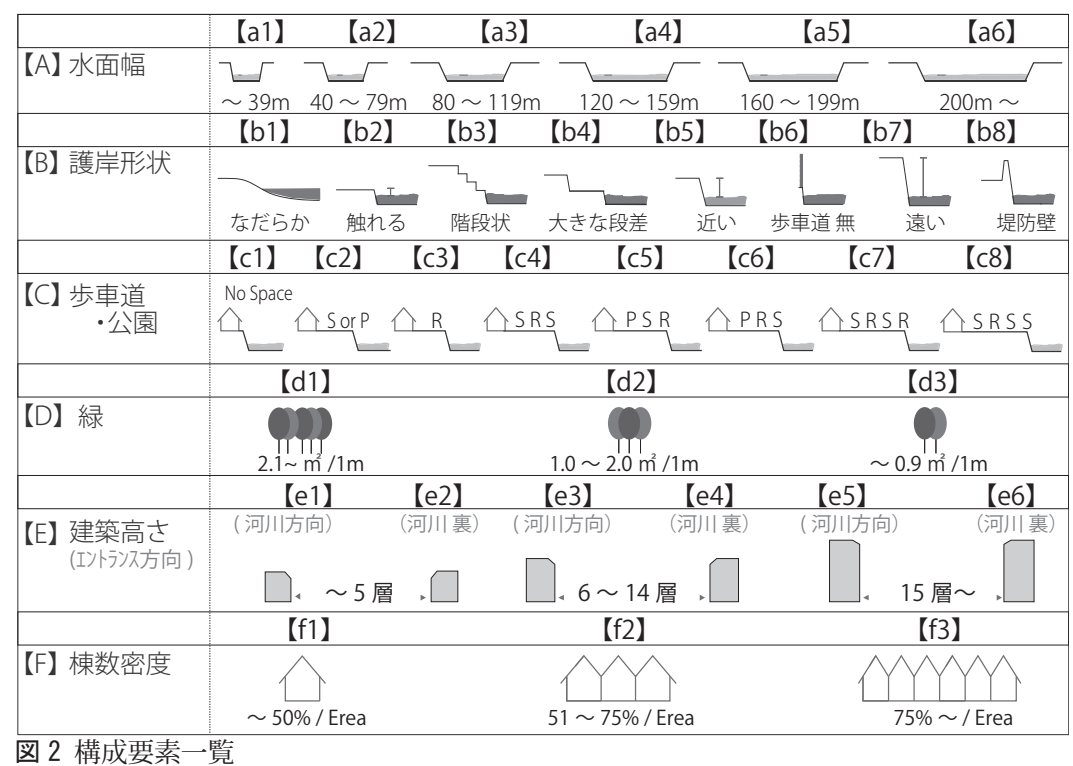
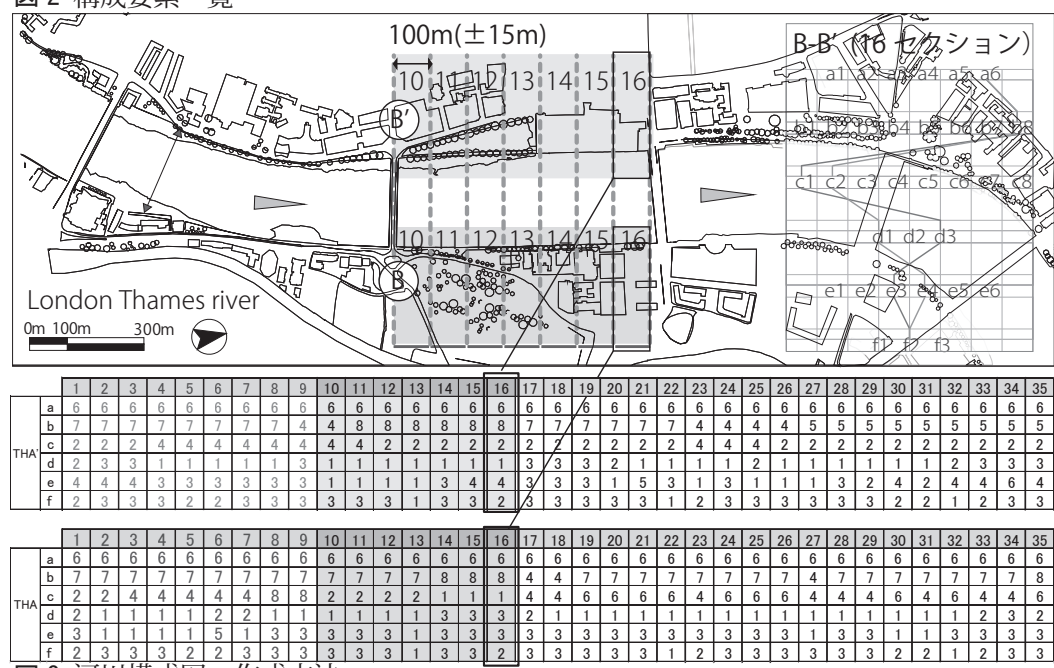

図 3 河川構成図 作成方法
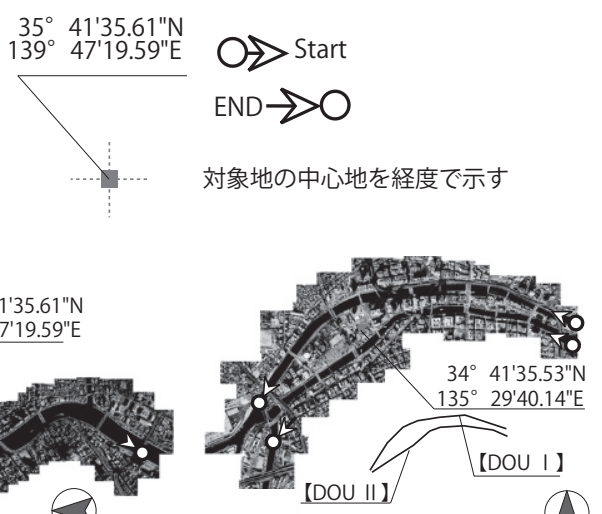

[SUM] TOKYO Sumida river
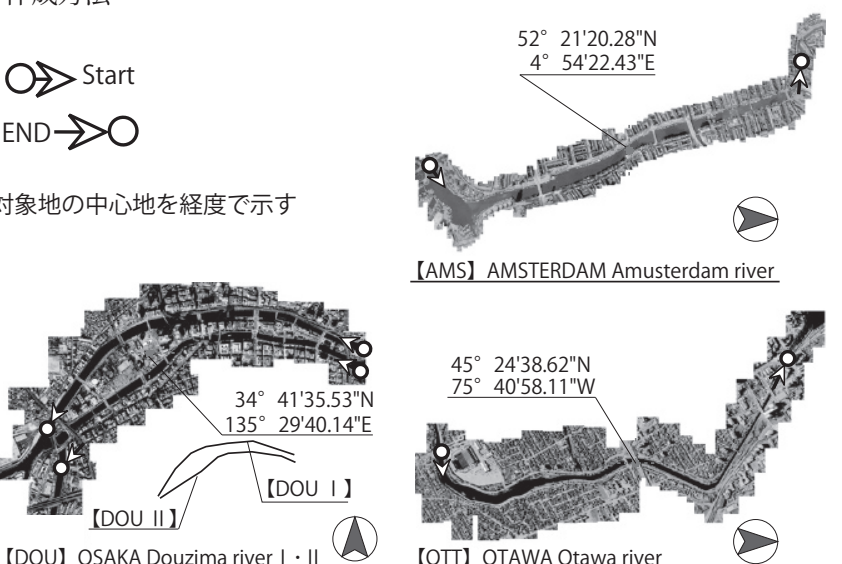

【AMS】AMSTERDAM Amusterdam river

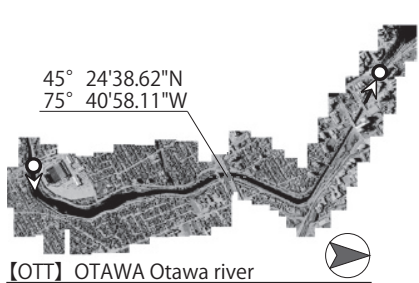

[SPR I • || \ BERLIN Spree river I • |

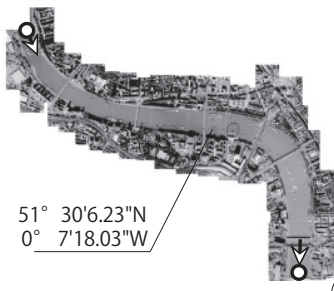

[THA】 LONDON Thames river

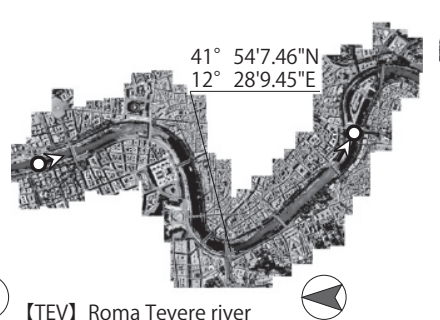

(A) [TEV】 Roma Tevere river

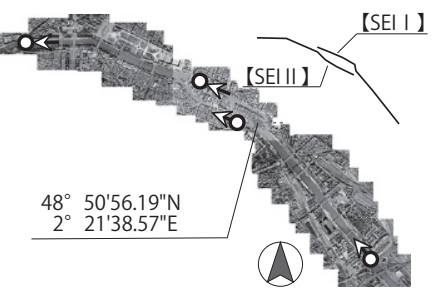

ISEI] PARIS Seine river $\mid \cdot \|$

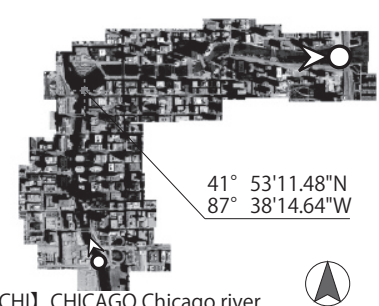


護岸のみを映した写真による親水性に関する心理的評価実験注7) を行 い b1 (親水性が高い) $\rightarrow$ b8 ( 低い) とした。さらに 1 区間を対象地 の橋 - 橋間距離の最短が約 $100 \mathrm{~m}$ であった事と併せ、街路景観に関 する既往論文 ${ }^{13)}$ 及び文献 ${ }^{14)}$ より視程距離が $100 \mathrm{~m}$ である事から 1 区間を約 $100 \mathrm{~m}$ に分割し、計 35 区間、両岸合わせ全 70 区間に分割し、

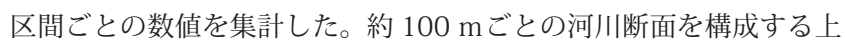
記の要素について 3〜8の形態に分けてそれぞれの該当箇所を結ぶ 構成図を考案した。この手法に基づき 1 区間ごとの構成図を作成し、 全 70 区間の線を重ね合わせ、重なった本数をもとに太さを変化注8) させ、河川構成図とした (図 4)。また、集計したデータを各河川の 構成要素ごとにグラフ化し、シーンの変化に伴う構成要素の変化点 および出現型を抽出しそれを基に分析を行う。

\section{4. 河川構成図による分析及び類型化}

作成した河川構成図をもとに一つの河川で多数構成されている要
素、即ち構成図で太く示される各要素の関係に着目すると、その河 川の骨格を示す構成が読み取れる。この構成図の形から類似した形 状の対象をまとめると 4 タイプに分ける事が出来る (図 4)。これ をもとに各々の特徴を分析する。TYPE- $a$; (SPR I .CHI .SPR II ) で は b5. 〈水面までが近い護岸〉にc2.〈歩道または公園〉が付属し、 f3.〈棟数密度 $-75 \%$ / erea〉の空間構成が共通的な特徵といえる。 またこれに加え SPR I では緑の量が多い・水面幅が 40 79m と狭 い・周囲が中低層の建物高さの構成である事が読み取れる。さらに CHI の構成として緑が少なく、高層の建物が多く、それらが高い棟 数密度で構成されている。SPR II ではSPR I と比べ水面幅が 39m とやや狭くなる区間が増え、緑の量が 1.0 2.0 m²/m に減少する特 徵を持つ。TYPE- $\beta$;(SEI I .TEV .SEI II ) では b4.〈大きな段差を持つ 護岸〉にc8. 〈歩 - 道 - 歩 - 歩〉 が付属し、 $\mathrm{d} 1$. 〈緑量 $2.1 \mathrm{~m} / \mathrm{m}$ 以上〉 緑が多く、f3.〈棟数密度 $-75 \%$ / erea〉の空間構成が特徴といえる。 それらの特徴に加え SEI I では 5 層以下の建物高さが多く高層の建

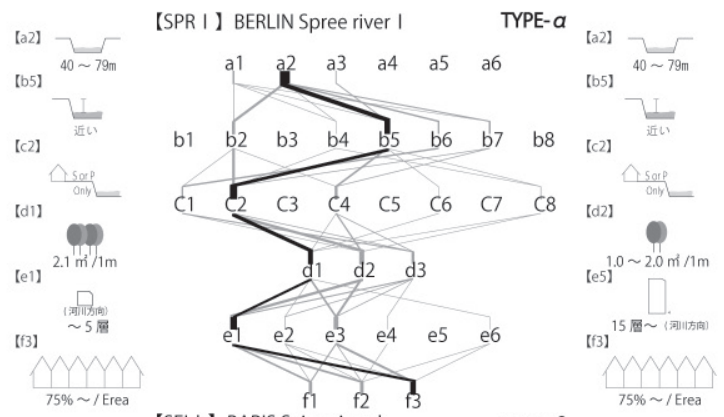

[SEI I PARIS Seine river I TYPE- $\beta$
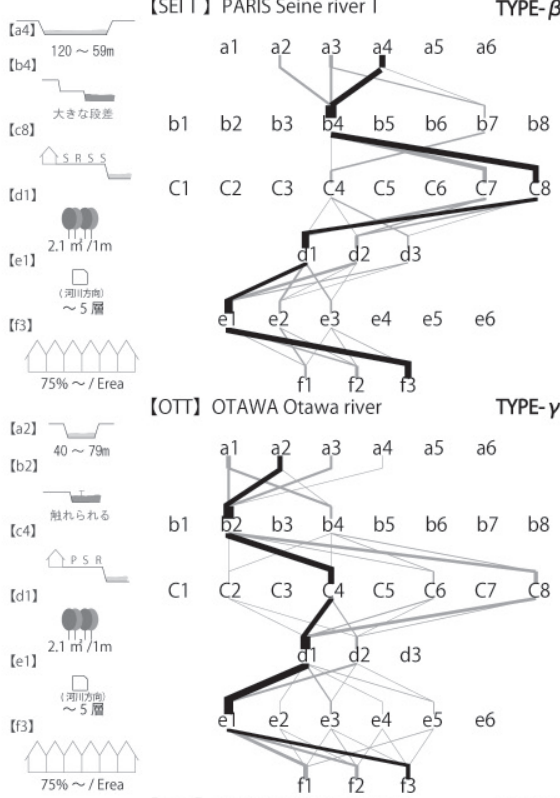

[THA] LONDON Thames river TYPE- $\triangle$

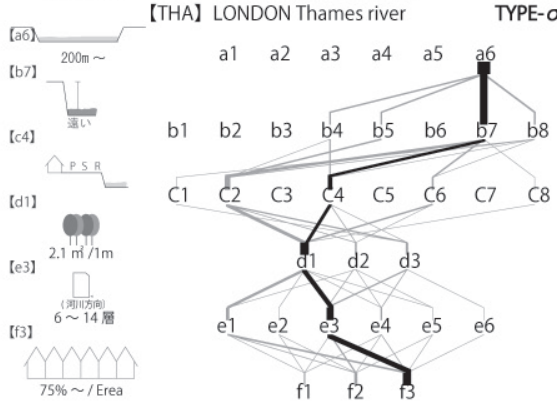

図 4 河川構成図一覧
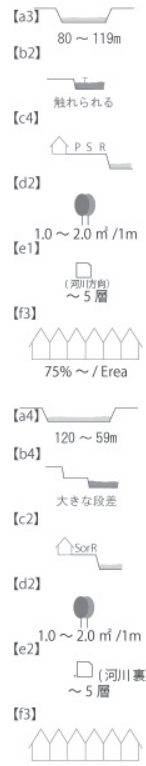

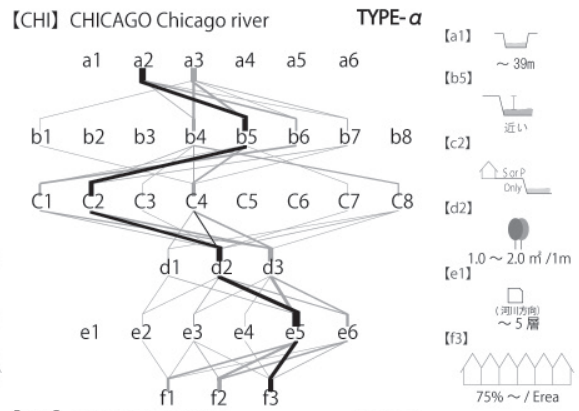

【SPR II \BERLIN Spree river ॥ TYPE- $a$

【TEV】 ROMA Tevere river

TYPE- $\beta$

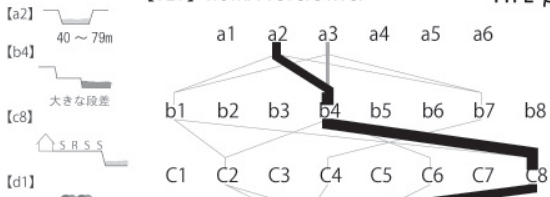

[a 4$] \underset{120 \sim 59 \mathrm{~m}}{\longrightarrow}$

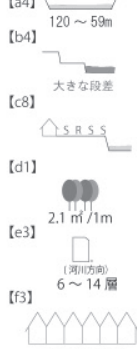

【SEI II \ PARIS Seine river II
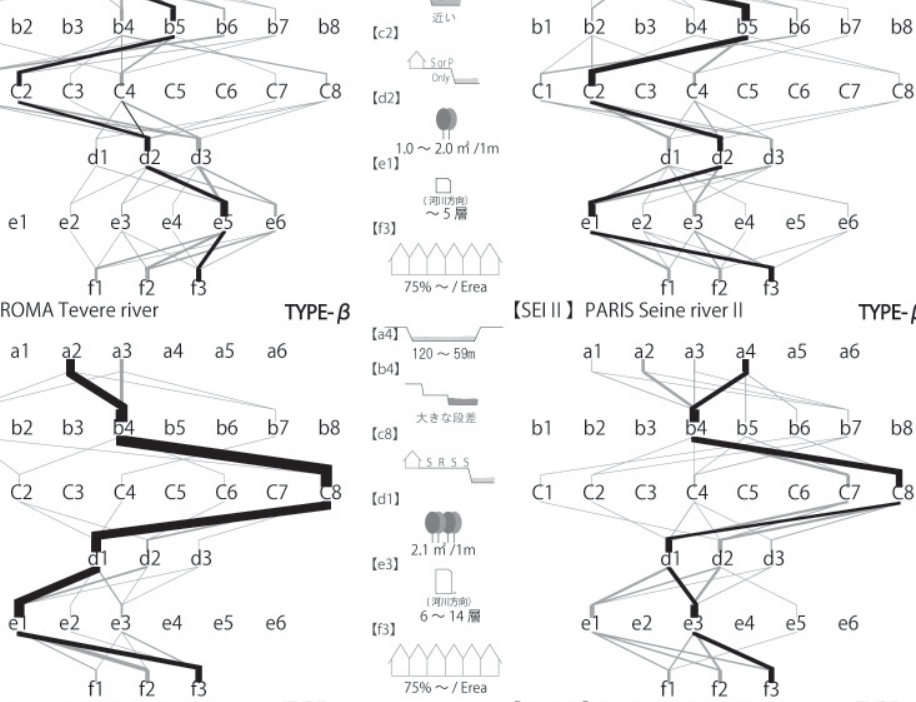

[AMS】 AMSTERDAM Amsterdam river TYPE- $\gamma$
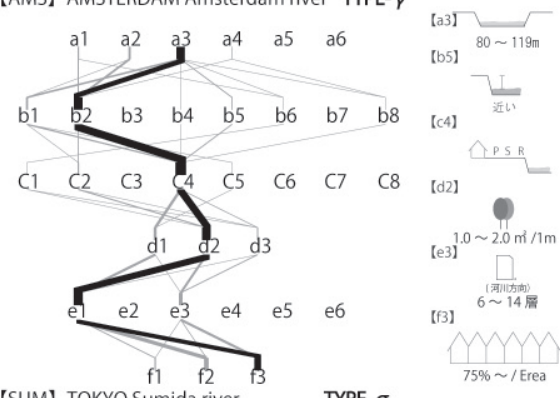
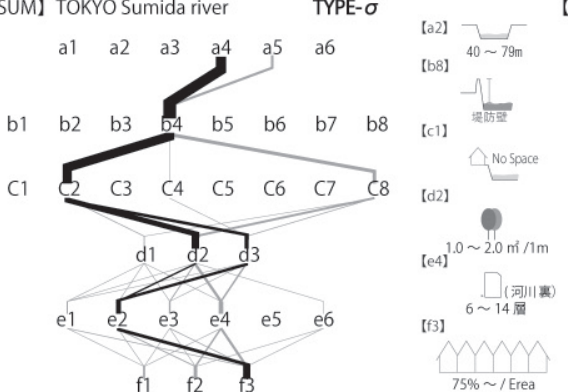
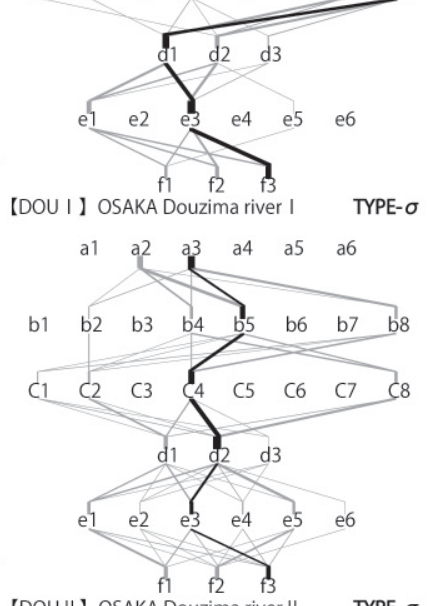

[DOU I] OSAKA Douzima river I TYPE- $\sigma$

[DOU II I OSAKA Douzima river II TYPE- $\sigma$

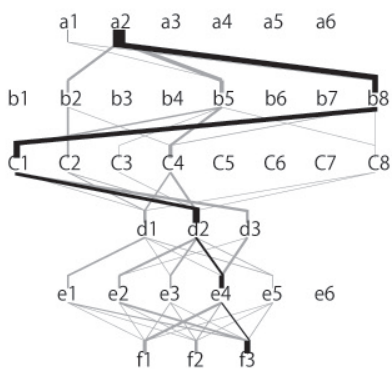


物がほとんど存在しない。また SEI II では、ほぼSEI I と同じ構成 を持つが建物高さが 6 14 層の構成が多く見られるなどの特徵があ る。さらに各要素間の繋がりが強く、出現する構成要素の数が少な い構成である事が読み取れる。これらとの差異として TEVでは水面 幅が 40 79m とやや狭く、さらにすべての要素に抢いて線の太さが 太く構成のまとまりが強い、即ち空間構成の変化が少ない河川空間 であると言える。TYPE- $\gamma$;(OTT .AMS) ではb2.〈水面に触れられる護 岸〉にc4. 〈歩 - 道路 - 歩道〉で構成され、e1.〈建物高さ 5 層以下〉 の高さを持つ空間構成が特徴といえる。それらの特徴に加え OTT で は水面幅が a2. 〈40 79m〉で緑が $\mathrm{d} 1 .\left\langle 2.1 \mathrm{~m}^{2} / \mathrm{m}\right\rangle$ と多く、棟数密 度が低いf1.〈 50\%/erea〉 区間と高いf3.〈75\% /erea〉 区間が混在 する特徵を持つ。また AMS では水面幅が a3.〈80 119m〉で緑が $\mathrm{d} 2 .\langle 1.0 \sim 2.0 \mathrm{~m} / \mathrm{m}\rangle$ 、棟数密度が高い f3. $\langle 75 \%$ / erea 〉の特徴を持つ。 TYPE- $\delta$; では $\alpha \beta \gamma$ で見られたような、【B. 護岸形状】【C. 歩車道・ 公園】の構成については共通の傾向が見られない。また特徴として、 【D. 緑】【E. 建物高さ】【F. 棟数密度】において多様な構成が混在して いるものであり、これをひとまとめのタイプとした。これらの特徴 に加え DOU II では水面幅が a 2. 〈40 79m〉で護岸形状に堤防壁を 持つ区間が多く存在し、それらと対応し河川と建物の間に歩車道空 間が存在せず、e4.〈6 14 層〉で建物エントランスが裏を向け、高 密度で形成されている特徴がある。またエントランスが裏を向けて いる特徵を持つ河川として SUM があげられ、差異として護岸形状が b4.〈大きな段差を持つ〉、に付随して歩道が計画される構成を持つ。 DOU I では水面幅が a3.〈80 119m〉で護岸形状が水面まで近い形 状を持つ区間が主要となる。さらに建物エントランスが表を向ける 区間が多く、同じ地区の DOU II と比較すると形態的特徴の差異がみ られる。THA では水面幅が a6.〈200m 〉と非常に広い幅を持つ区 間が多く、b7.〈水面までの距離が遠い〉護岸形状が特徴といえる。

\section{5. 全対象における構成要素割合}

12 対象の全 840 区間における構成要素ごとの割合を表 1 に示す。 【A. 水面幅】に挄いて最も多いのは a $2\langle 40 \sim 79 \mathrm{~m}\rangle$ の 336 区間 (40\% . カッコ内は全対象区間 840 区間中の割合を示す) で次いで多いのは a3〈80 119m〉の 195 区間 (23\%) であった。【B. 護岸形状】では b4〈大きな段差を持つ〉の 312(37\% )、b5〈水面に近い〉の 184 区間 $(22 \%)$ 。【. 歩車道・公園】において最も多い構成タイプは c4 〈歩・車・歩〉の 253 区間 $(30 \%)$ 、次いで多いのは c2〈歩・公〉の 228 区間 $(27 \%)$ で河川に面して歩道・公園などのオープンスペース が約 7 割を占めている事がわかる。【D. 緑】において最も多い構成タ イプは $\mathrm{d} 2\langle 1.0 \sim 2.0 \mathrm{~m} / \mathrm{m}\rangle$ の 351 区間 (42\%) で、次いで多いのは $\mathrm{d} 1\left\langle 2.1 \mathrm{~m}^{2} / \mathrm{m}\right.$ 以上〉の 346 区間 $(41 \%)$ 、即ちほとんどが、 $1 \mathrm{~m} / \mathrm{m}$ 以上の緑が河川沿いに植えられている特徵がある。【E. 建物高さ】に おいて最も多い構成タイプは e1〈 5 層〉の 357 区間 (43\%) で、次 いで $\mathrm{e} 3\langle 6 \sim 14$ 層〉の 228 区間 $(27 \%)$ 。また【F. 棟数密度】は $\mathrm{f} 3\langle 75 \%$ /erea〉の 402 区間 (48\%) 、次いで f2〈51 75\%/erea〉の 251 区 間 (30\%) である。これらから対象とした大都市における河川沿いの 空間構成は総体として大きな段差を持つ護岸や水面に近い護岸形状 に歩道や公園が付随するなどアクティビティーを誘発させるような 計画がなされている事がわかり緑量が多く低層、高密度な計画がさ れている特徴が読み取れる。模式図として図 5 に示す。
表 1 構成要素の割合一覧

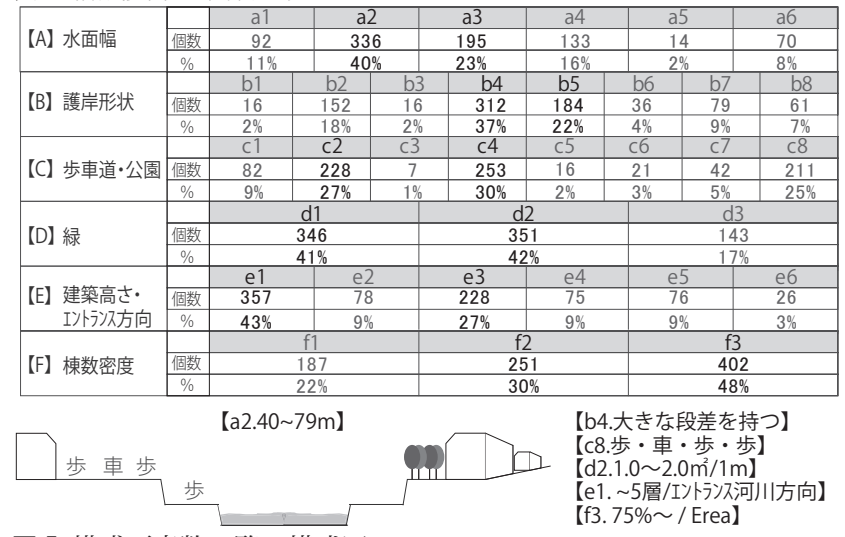

図 5 構成要素数一覧・模式図

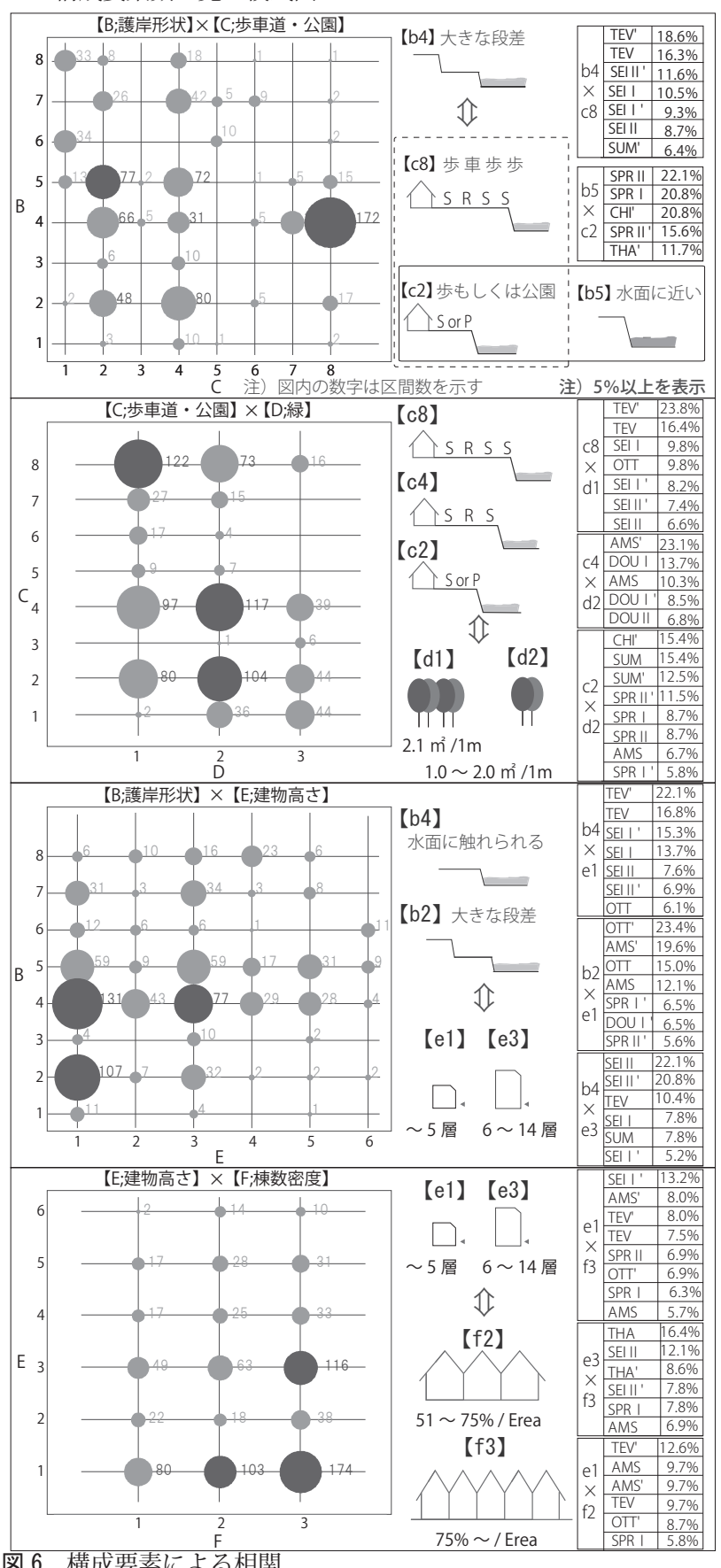




\section{6. 構成要素の相関分析}

図 6 に示すように 12 対象 840 区間全ての構成要素について組み 合わせの数量を基に相関分析を行った。【B. 護岸形状】と【C. 歩車 道・公園】では $\mathrm{b} 4$ と $\mathrm{c} 8 . \mathrm{c} 2$ の関係が強く、大きな段差を持つ護岸に は段差部分に〈歩道〉もしくは〈歩道・公園〉が付属する傾向があ る。これから大きな段差を持つ護岸形状ではアクティビティを誘発 させるような歩道・公園などの計画がなされる傾向がある。これら は TEV・SEI I ・SEI IIに多くみられる特徴で、b4-c8 の組み合わせ の約 $35 \%$ tEV が占めている。河川構成図からも見て取れ、明らか に線の繋がりが太く構成に結びつきが強く、区間内において構成が 変化しにくい事が読み取れる。さらに【C. 歩車道・公園】と【D. 緑】 の関係を見ると c2.c4.c8 のように歩道・公園などが河川沿いにある 構成には緑量が多く計画されている。また【B. 護岸形状】E. 建物高さ】 では b2.〈水面に触れられる護岸〉と e 1. 〈 5 層高さ〉の関係が強い 事から水面に触れられる形状を持つ護岸には低層の建物が多く計画 される傾向がある。さらに護岸形状の親水性における評価実験で高 く評価された b1.b2.b3 の形状には高層建物の分布が少なく e1.e3に 見られる低・中層に多く分布している。【E. 建物高さ】と【F. 棟数密度】 との関係を見てみると、大都市における河川空間では中・低層の建 物が高密度に計画されている事が特徴として読み取れる。

\section{7. シークエンス分析}

\section{7-1 構成の出現パターン抽出}

各対象に扔いて川上から川下の流れの中で、各構成要素ごとのシー クエンシャルな変化を図 10.11 に示し、分析を行う。まず各対象に 見られた構成要素の出現型の抽出を行い、以下に示す 3 タイプおよ びそれらの複合型として示した。出現型の算出の概念図を示す (図 7)。 RANDOM 型《RAN. カッコ内は略称を示す》; 構成にまとまりがなく 複数の構成要素が規則性なく表れる。UNIT 型《UNI》; 同一の構成が 連続して 5 区間以上、出現する。RETURN 型《RET》; 2 3 つの異な る構成要素が細かく規則的に繰り返し出現する。これらの 3 つ出 現型が各要素それぞれで単体もしくは組み合わさり、都市の河川形 態を構成していることがわかる。

\section{7-2. 変化数量による分析}

構成要素ごとの変化数を算出し (図 8) 考察を行う。算出方法を図 9 に示す。全体を通してもっとも構成要素の変化数が多い対象はSPR I (140. カッコ内は変化数を示す) で水面幅を除くすべての要素で変 化数 (20) 以上の変化数がある事から区間によって空間構成が変わり やすい対象といえる。一方、最も変化数の少ない対象は TEV(71)で あった。これれらを出現タイプで見てみると変化数の多いSPR I は 【B. 護岸形状】を除くすべての構成要素で《RAN 型》の付属したパター ンを持ち、変化数の少ない TEV ではすべての要素で《UNI 型》のパター ンを持つことが特徴として見て取れる。【A. 水面幅】において最も変 化が多いのは TEVの（13）だが a $\langle 40 \sim 79 \mathrm{~m}\rangle \cdot \mathrm{a} 3\langle 80 \sim 119 \mathrm{~m}\rangle$ に すべてが該当する。また THA a6〈200m 〜 >.SUM a5〈160〜 $190 \mathrm{~m}\rangle$ においては変化数がほぼなく水面幅がほぼ変わらない対象といえる。 全体の傾向として水面幅には大きな変化数をもつ対象がない事が見 て取れた。【B. 護岸形状】において最も変化数が多いのは AMS の (27) でほかの対象と比べても多く、多様な護岸形状の種類を持つといえ

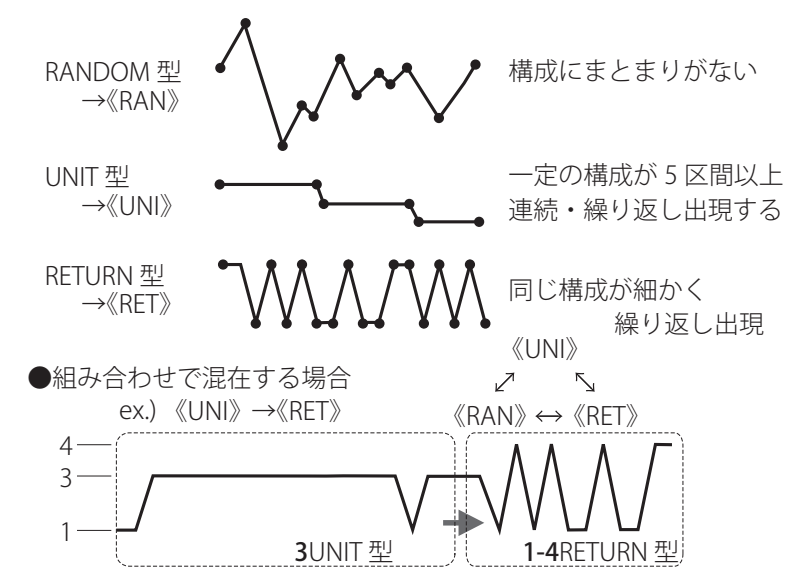

図 7 出現型の概念図

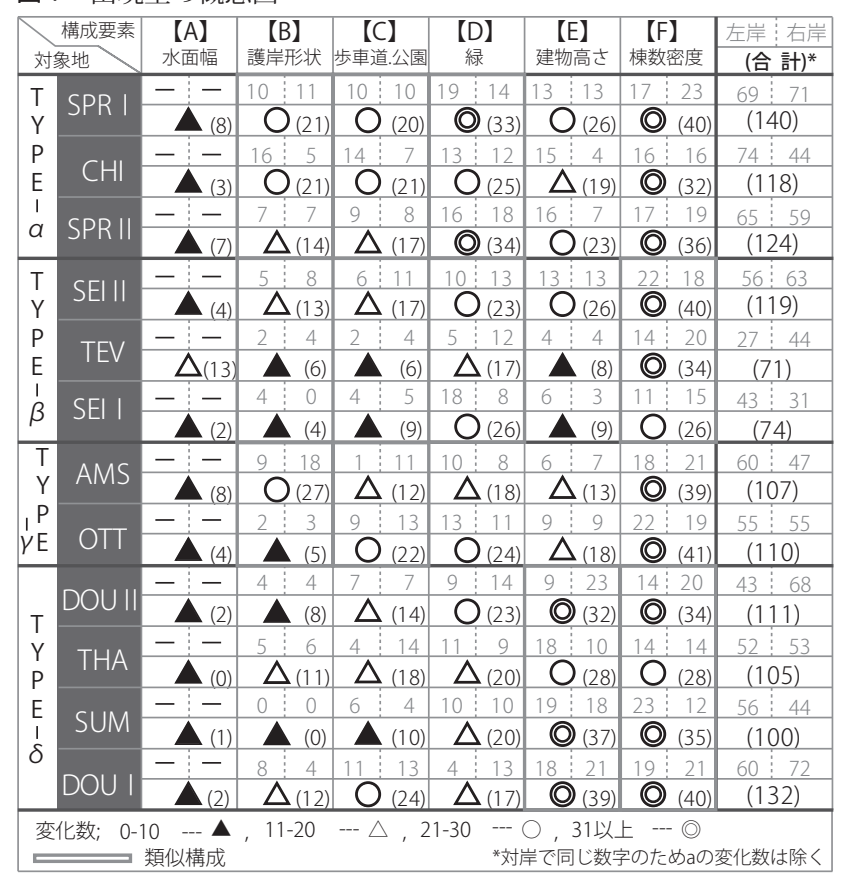

図 8 変化数一覧

\begin{tabular}{|c|c|c|c|c|c|c|c|}
\hline 構成要素 & $\mathrm{a}$ & b & c & $d$ & e & $\mathrm{f}$ & 区 \\
\hline 厂 区間 X & 3 & 2 & 1 & 11 & 1 & 3 & \\
\hline$\rightarrow$ 区間 $X+1$ & 3 & 4 & $\downarrow 1$ & 3 & $\checkmark 1$ & 3 & $x+$ \\
\hline 変化数 & 0 & 1 & 0 & 1 & 0 & 0 & \\
\hline
\end{tabular}

図 9 変化数算出方法

る。また SUM(0).SEI I (4) では護岸の形状にほぼ変化がなく両対象 とも、ほぼ b4〈大きな段差を持つ〉の《UNI 型》で構成されている。 また【C. 歩車道・公園】に拈いて変化数が多いのはDOU I (24)で 次いで多いのは OTT の (22) であった。一方、変化数が少ない対象と して TEV.(6) があげられ、ほとんどが c8. 〈歩 - 道 - 歩 - 歩〉の《UNI 型》で構成されている。【D. 緑】は全体を通して変化数が多い構成要 素と言え、変化数が多いのは SPR II (34).SPR I (33) で、変化数が 少ない対象として TEV(17) でほぼ $\mathrm{d} 1\left\langle 2.1 \mathrm{~m}^{2} / \mathrm{m}\right.$ 以上〉の《UNI 型》 である。【e. 建物高さ】において多い変化数は DOU I (39).SUM(37) で両対象が TYPE- $\sigma$ に類型される事から変化数 (30) を超える特徴が

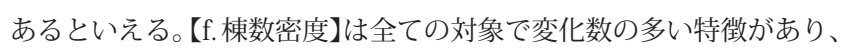
ほぼ《RAN 型》で構成される。またこれらから変化数の多い構成に 
は《RAN 型》及び《RET 型》が必ず付随し、変化数の少ない構成に は《UNI 型》が多く付随する特徵が読み取れる。

\section{7-3. 対岸の変化数における対称性}

変化数一覧 (図 8)、及びシークエンス図 (図 10.11) より、対岸の 変化数の違いにが多い対象に着目した。CHI では右岸に比べ、左岸 の変化数が圧倒的に多い。これらは【B;護岸形状】C ; 歩車道・公園】 建物高さ】に見られる特徴で、シークエンス図からも見て取れるよ うに左岸の後半にかけて《RAN 型》の構成が多いのに対して右岸で は全体を通して《UNI 型》の構成が多い事が見て取れる。また DOU IIでは【D;緑】【E;建物高さ】に変化数の差異がみられ、左岸では【D】 【E】とも《UNIT 型》の構成を持つのに対し、右岸では【D】【E】が《RAN 型》《RET 型》で構成されていることがわかり、対岸でアシンメトリー な構成を持つことがわかる。さらに SEI II では対岸の変化数の差異 はそれほど多くないが、ノートルダム大聖堂を境に左岸の構成の多 くが《UNI 型》から《RAN 型》《RET 型》に変化するのに対し、右岸 の構成の多くがパリ植物園を境に《RAN 型》《RET 型》から《UNI 型》 へ変化している。即ち左岸では後半につれて構成の変化数が増加し、 右岸では後半に変化数が減少するといった対岸でアシンメトリーな

【SPR | \BERLIN Spree River | 注）数字は区間を示し、ロは橋区間を示す。

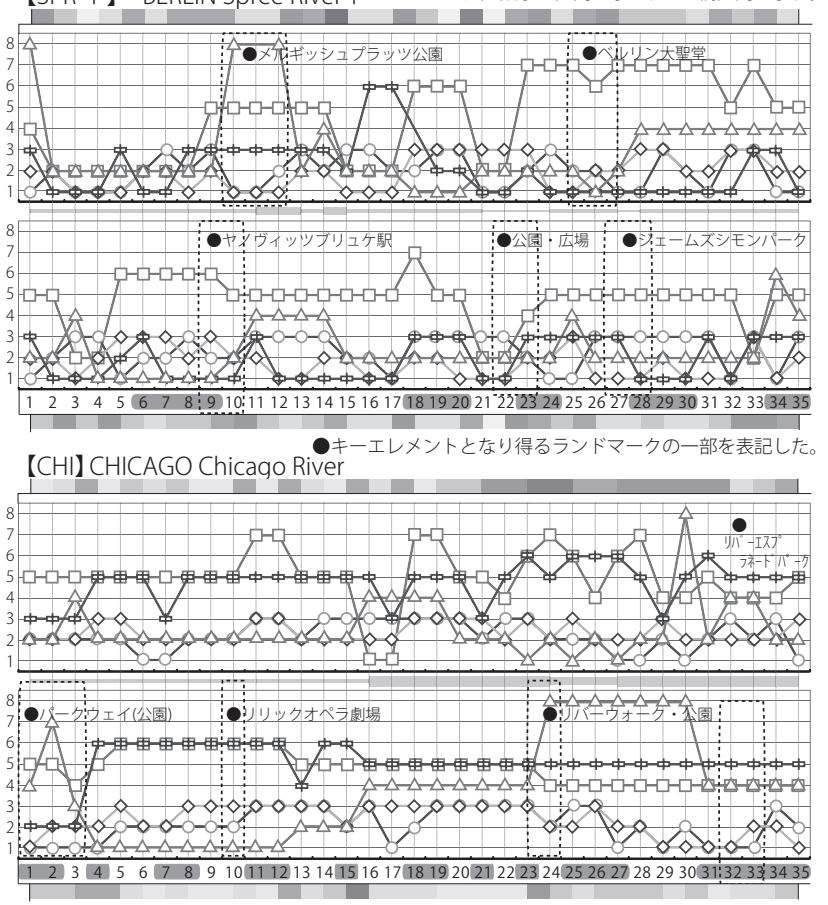

【SPR ||】BERLIN Spree River I|

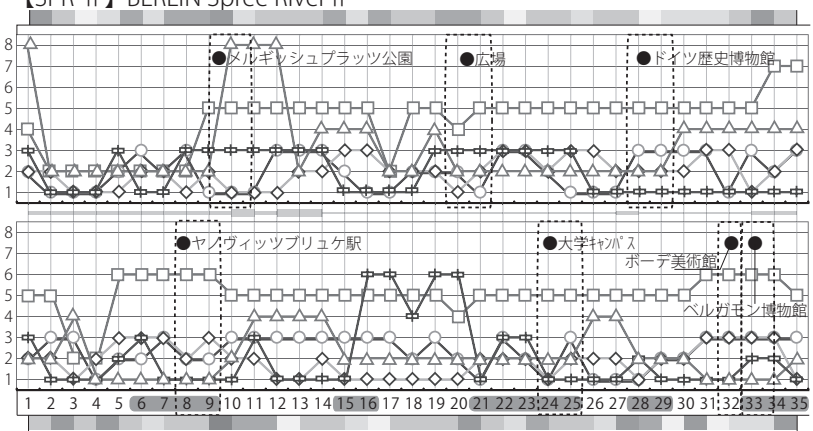

図 10 シークエンス図 1
空間構成を持つといえる。

\section{7-4. TYPE 別による変化数}

近しい構成を持つタイプごとの変化数の違いについて考察する。 TYPE- $a$; (SPR I .CHI .SPR II ) は全体として変化数の多いタイプと言 え、シークエンス図から、【B】【C】の出現タイプを見るとSPR IIで は《UNI 型》もしくは《RET 型》で構成されているのに対し SPR I .CHI では、《RAN型》が多く、変化数に差異が見られたと考察できる。 TYPE- $\beta$;(SEI I .TEV .SEI II ) では【B;b4】【C;C8】が類似したタイプ で、全体として変化数が少ないと言えるが SEI IIに比べ SEI I .TEV の変化数がやや少ないことが見て取れる。出現タイプから SEI II《UNI 型》に《RET型》が付随するのに対し、SEI I .TEVではほぼ《UNI 型》 で形成されている。TYPE- $\gamma$; (AMS .OTT) では【B;b2】【C;c4】が類 似したタイプで、AMS の【B;b2】護岸形状では《UNI 型》に《RET 型》 が付随するのに対し、OTTではほぼ変化のない《UNI 型》で形成さ れている特徴がある。一方、【C;C4】歩車道・公園においては出現パ ターンが逆転し、AMS《UNI 型》に対し OTT《RAN 型》の構成を持

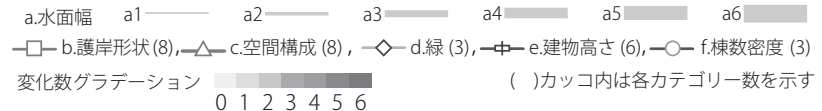

【TEV】 ROMA Tevere River

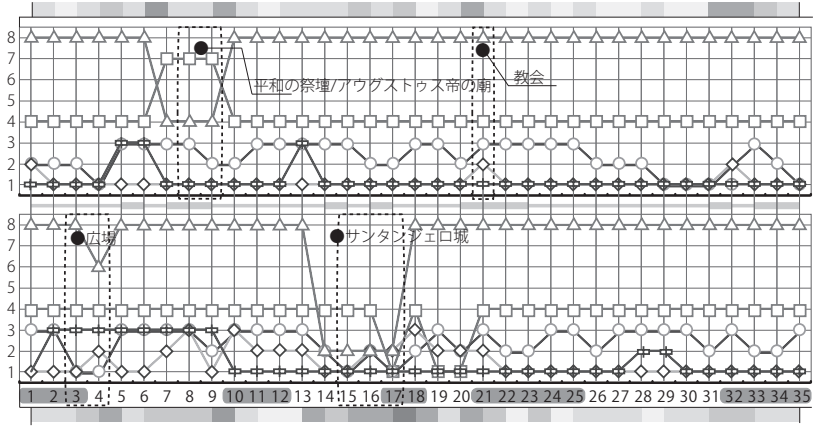

【SEI I 】 PARIS Seine River |

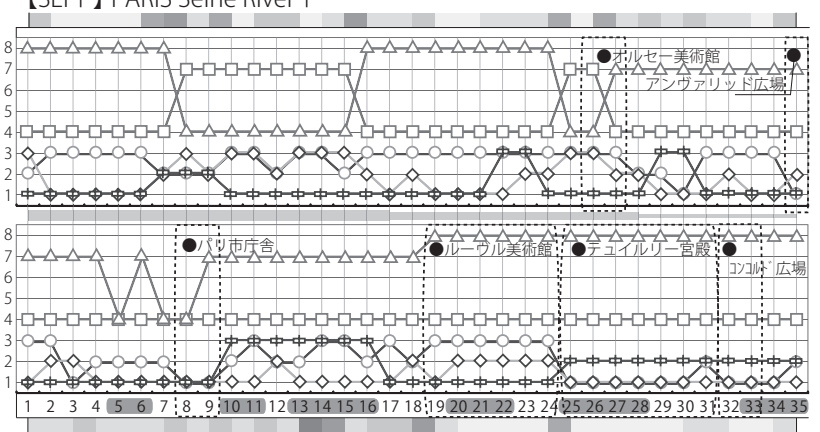


つ。TYPE- $\delta$; (DOU I .THA .SUM .DOU II ); 【E】【F】に類似した構 成がみられ、それにおいては、ほぼ《RAN 型》に、《RET 型》が付随 している事から建物高さ、棟数密度に变化が多い特徴が見て取れる。 これらのように総体として類似した構成をもつ河川空間においても 対象都市によって出現型が異なる場合があり各々の形態的特徵があ るといえる。

\section{7-5. 各対象ごとのシークエンス分析}

作成したシークエンス図 10.11 から要素ごとの変化数を求め、特 徵的であった対象の区間について空間構成の変化点となり得るキー エレメント ${ }^{15}$ との出現と併せ対象の分析を行う。また図 8.9 にはキー エレメントとなり得るランドマークの一部を表記し変化数の増加に 伴うグラデーションを表記した。「SPR I」では左岸 25-27 区間で変 化が多く見られ【D.d1: 緑多】から【d3: 緑少】【E.e1: 低層表】から【e2: 低層裏】、F.f3: 高密度】から【f2: 中密度】へ变化している。その区 間にはベルリン大聖堂が位置しその前方に計画された広場等が変化 点と考えられる。また左岸 9-11 区間でヤノヴィッツブリュケ駅・線 路の存在により【B.b5: 水面に触れられる】から【b6: 歩車道を有さ ない】【C.c2: 歩道・公園】から【c1:No Space】へ構成が変化している。

【OTा】 OTAWA Otawa River

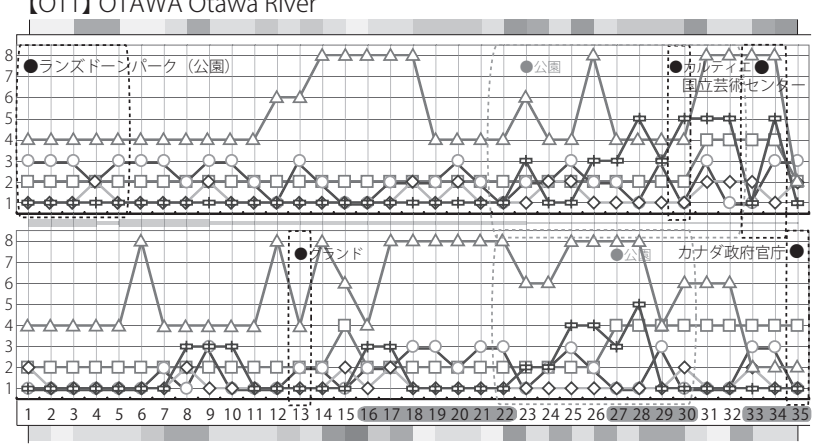

[DOU । 】 OSAKA Douzima River |

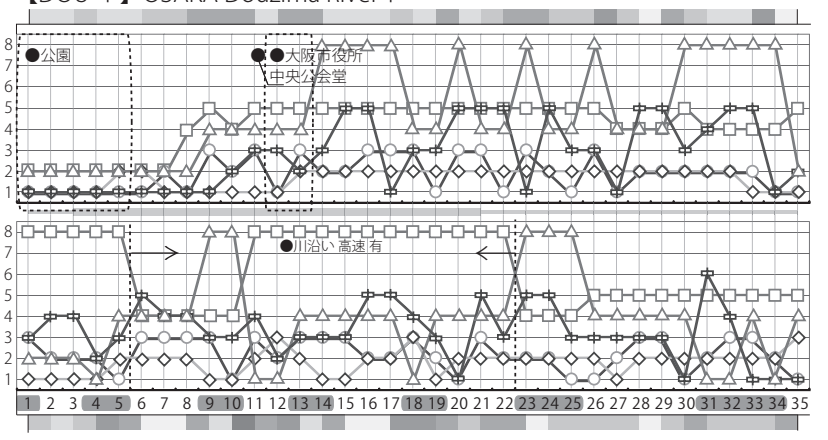

【DOU II OSAKA Douzima River I|

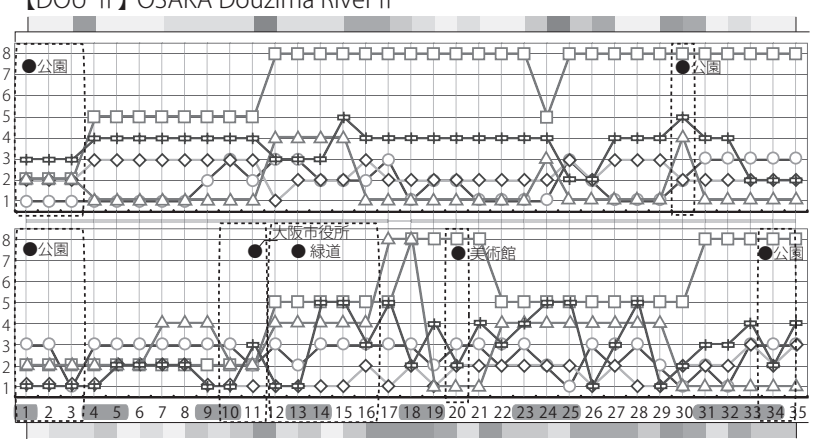

図 11 シークエンス図 2
「CHI」では前述のように対岸の出現タイプ、変化数の違いが顕著に みられ左岸では《RAN 型》《RET 型》の付随が多いのに対し右岸では 川下に進むにつれ (b6: 歩車道を有さない)-(b5: 水面まで近い)-(b4: 大 きな段差) の変化が《UNI 型》でみられる。またランドマークや広場 など変化点としてキーエレメントになり得る要素が少ない左岸にお いて変化数が多く見られた。CHI の特徴として橋 - 橋間の距離が短く それらの中で構成が完結している。これらから橋も空間の変化点に なり得、構成変化のキーエレメントの役割を持つと考えられる。「SPR II」でも右岸の 5-6 区間、20-21 区間など橋 - 橋間での変化数の増 加が多く見られた。また左岸、9-12 区間のメルギッシュプラッツ公 園や 19-21 区間の広場の出現による緑量の【D.d2: 有】から【d1: 緑 多】への変化も顕著にみられる。「SEI II」の変化数の多い区間は右 岸 26-28 区間で【B.b4: 大きな段差の護岸】から【b7: 水面までの距 離が遠い護岸】、C.c4: 歩道・車道・歩道】から【c2: 歩道・公園のみ】、 【D.d2: 有】から【d1: 緑多】へ変化している。その区間にはノートル ダム大聖堂が位置し、特徵的な広場や植栽の計画が変化数の増加に 影響していると考えらえれる。また左岸の 16-25区間で、【D.d2: 緑有】 から【d1: 緑多】【E:e3 中層】から【e1: 低層】へ変化し、変化点のキー エレメントとしてパリ植物園とヴァルベール広場があげられ、緑地

【AMS】AMUSTERDAM Amusterdam River

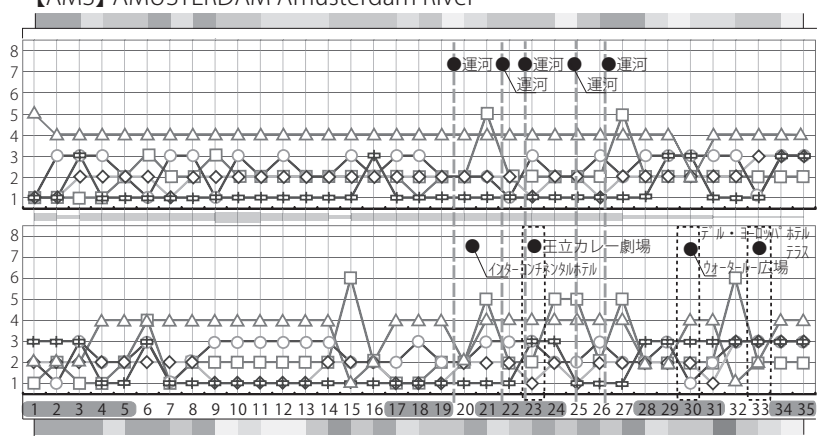

【THA】 LONDON Thames River

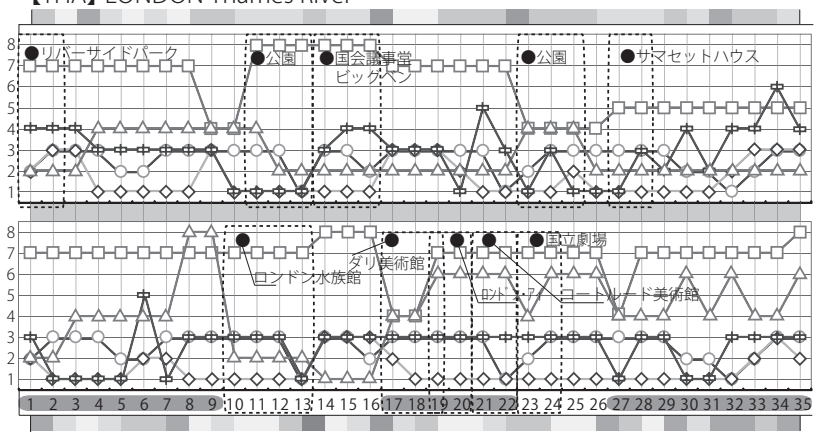

【SUM】 TOKYO Sumida River

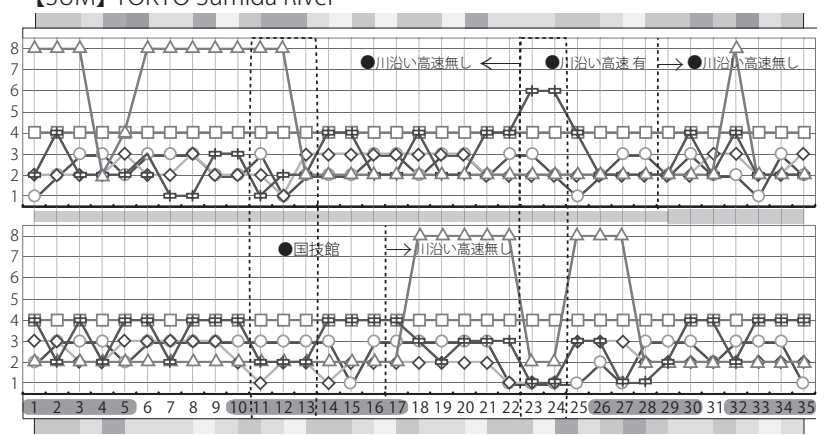


計画などから空間が大きく開かれたと言える。「TEV」では前述のよ うに両岸がほぼ【b4: 大きな段差を持つ】(c8: 歩車歩歩】【d1: 緑多】(e1: 低層】の《UNI 型》【f2: 中密度】【f3: 高密度】の《RET 型》で構成さ れている。歴史的建造物が連続し建つ区間で変化が少ない特徵を持 つといえる。一方、右岸 14-17 区間に位置するサンタンジェロ城 の 出現とともに【c8: 歩車歩歩】から【c2: 歩・公園】【D.d2: 有】から【d1: 緑多】などの変化もみられる。「SEI I」の左岸では 1-6 区間まで【b4: 大きな段差を持つ】【c8: 歩車歩歩】の《UNI 型》の組み合わせが続 き、河川沿いを歩行専用道として歩く事ができるが、 7 区間の橋を境 に構成の組み合わせが変化し、【b7: 水面まで遠い護岸】【c4: 歩車歩】 の《UNI 型》の組み合わせに変化する。一方、対岸ではルーブル美 術館、コンコルド広場などが連続する 19-35 区間では変化の少ない 《UNI 型》が連続し、ルーブル美術館を境に【c7: 歩車歩車】から【c8: 歩車歩歩】に変化し護岸沿いを歩ける構成になる。「OTT」は橋の数 が少なく前半部においては橋 - 橋間が長いスパンを持つ特徵があり、 【b2: 水に触れられる】【c4: 歩車歩】【d1: 緑多】の《UNI 型》に《RET 型》付属で構成されている。16 区間を境に後半にかけて変化数が増 え、右岸カルティエスクエア、国立芸術センター付近に拈いて、【C: 歩車道・公園】【F: 棟数密度】に《RAN 型》の構成が出現する。「DOU I」は構成の変化数が多く【b8: 堤防壁】【b5: 水面に近い】の《UNI 型》を除くほとんどの構成で《RAN 型》《RET 型》の変化がみられた。 特筆すべき点として、【E: 建物高さ】の変化数が最も多く統一性のな い構成と言える。また変化点として、右岸 22 区間の高速道路があげ られ【b4: 大きな段差】から【b7: 水面までの距離が遠い】、c4: 歩車 歩】から【c8: 歩車歩歩】などの変化がみられた。これらに見られる ように変化点となり得る都市的構成要素には高速道路なども含まれ、 空間の䨌囲気の変化点として存在することがわかる。

\section{8. まとめ}

以上の分析を通して、主に以下の点を明らかにした。 河川構成図の考案より記号化表現として河川空間の構成を総体とし て表す手法を示し、その結果、TYPE- $a$;b5.〈水面までが近い護岸〉 に c2.〈歩道または公園〉が付属し、f3.〈棟数密度 $-75 \%$ / erea〉 の高い空間構成。TYPE- $\beta$;b4. 〈大きな段差を持つ護岸〉にc8. 〈歩 道 - 歩 - 歩〉が付属し、 d 1. 〈緑量 $2.1 \mathrm{~m}^{2} / \mathrm{m}$ 以上〉緑が多く、f3.〈棟 数密度 $-75 \%$ / erea〉の空間構成。TYPE- $\gamma$; (b2.〈水面に触れられ る護岸〉に c 4. 〈歩 - 道路 - 歩道〉で構成され、e1. 〈建物高さ 5 層以 下〉の高さを持つ空間構成。TYPE- $\delta$; 【B. 護岸形状】【C. 歩車道・公 園】の構成については共通の傾向が見られなく、【D. 緑】【E. 建物高さ】 【F. 棟数密度】において多様な構成が混在している空間構成。の 4 タ イプを類似として示した。

また各構成要素の出現型として以下に示す 3 タイプを抽出した。 それぞれの河川空間は以下の 3 つの型で構成される。

(1) RANDOM 型; まとまりがなく複数の構成要素が規則性なく表れる タイプ。

(2) UNIT 型; 同一の構成要素が 5 区間 (500m) 以上連続するタイプ。

(3) RETURN 型；2 3 つの異なる構成要素が規則的に繰り返し出現す るタイプ。

さらに各都市の河川空間に存在する象徵的な空間構造は、歴史的 建造物やキーエレメントとなりうる都市的構成要素が空間のアクセ
ントとなりそれらをもとに変化数の顕著な増加が見られた。またそ れらの変化点は参道空間における分節点と対応するものである。参 道の物理構成と比べて、河川空間の変化点の場合、都市的構成要素 であり象徵的なランドマークになり得る歴史的建造物や橋、広場、 公園や船場などと対応するものと考察できる。参道においては本社、 本殿のアプローチ空間として心理的な抑揚を促すものであったが、 河川空間に抢いては、都市景観あるいは、都市のアメニティ形成上 のアイストップやビューポイントとしてキーエレメントとなり得、 雰囲気やアイデンティティを形成しうる関係にあるといえよう。 また変化点の構成モデルを図 12 として示すと、1. 水面幅の変化 2. キーエレメントの出現 3. 橋. 船場の出現 4 . 規則性なく変化を繰 り返す5. 歴史的町並みの境、などの変化点と空間を構成する要素 との関係が読み取れた。

今後は本研究で明らかにした形態的特徵のシークエンシャルな変 化と対応させ、分節点ならびに構成要素との心理的評価の相関関係 を明らかにしていく予定である。

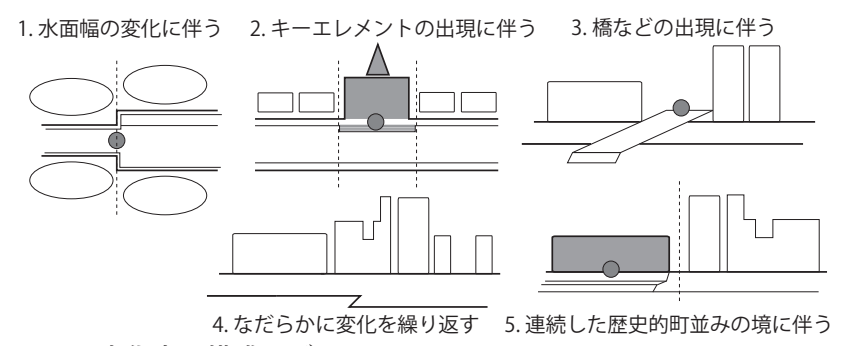

図 12 変化点の構成モデル

\section{謝辞}

本研究にあたって、基礎資料作成、及びデータ集計に協力して下 さった榎本章宏氏・木藤雄太氏・依田悠介氏に深く感謝いたします。

注

注 1）心理評価実験で得られた、各対象地の心理量を基にクラスター分析（最 長距離法）により類型化を行い《意識型》とした。

注 2）河川空間を表す、水面の幅、河川沿いの道、建築、緑、の 4 項目を設定し、 クラスター分析（最長距離法）により類型化を行い《形態型》とした。

注 3）空間の雾囲気を不連続に変化させるような空間の区切りを分節点と定 義した。

注 4) ゲーテが初めて使用した言葉であり、ラフバラー大学で行われてい た初期研究の成果をもとにGaWC (Globalization and World Cities Study Group and Network）が主要な世界都市を「第 1 級世界都市、「第 2 級世界都市」「第 3 級世界都市」に分類し、計 10 のカテゴリを定義 しており都市名の国際的な知名度が高い、世界規模での国際貢献があ る、通常数百万人規模の人口がある大都市などから定められている。

注 5) Vector Works 2010

注 6)【A. 水面幅】は、1区間で3 地点測定を行い、平均值を用いた。Ⓑ. 護岸形状】 は写真を基に模式図を作成した。【C. 歩車道・公園】は河川から最も近 い建築群までの構成とし、主な要素を歩道 $(\mathrm{s})$ ・車道 $(\mathrm{r})$ ・公園 $(\mathrm{p})$ と定め、 それらの配置順序・組み合わせを集計した。【E. 建物高さ】は 1 区間内 における全ての建物高さの平均としたが、ランドマークなど突出した建 物高さは除外した。【F, 棟数密度】においては、区間内の建物間口長さ の合計 / 区間内の道路長さで算出した。

注 7）評価実験は、80 インチのスクリーンにプロジェクターで投影した画像 を被験者（建築学科の学生計 35 名; 男 21 名, 女 14 名) に見せ、そ の写真の親水性（水に触れたい・水辺に留まりたい等）について S D法 
を用い評価してもらった。提示した写真は予め8 タイプの護岸形状に類 型し、各タイプ 5 対象ずつ、計 40 枚を対象とした。実験に使用した写 真の一例を下記に示す（写真 1.2.3）。

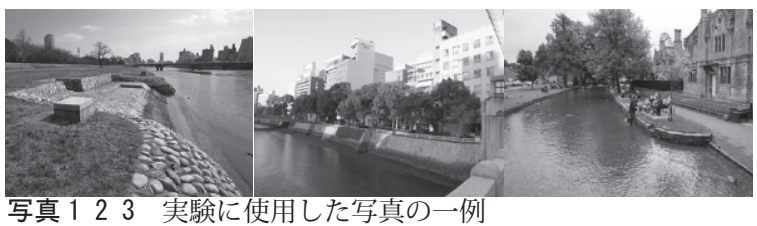

注 8） 1 区間の太さを $0.25 \mathrm{pt}$ とし、重なった本数分 $0.25 \mathrm{pt}$ を加算した。

\section{参考文献}

鈴木 規道，積田 洋，津村 佳余：河川空間の心理的評価と護岸断 面形状ならびに空間構成との相関分析 日本建築学会計画系論文集，第 672 号, pp. 372-333, 2012.2

渡辺 秀俊, 畔柳 昭雄, 近藤 健雄 : 都市住民の親水行動特性に関寸 る研究（その1）日本建築学会計画系論文報告集, 第449 号, pp. 151161, 1993. 7

3）畔柳 昭雄, 渡辺 秀俊, 長久保 貴志 : 都市住民の親水行動特性に関 する研究（その 2) 日本建築学会計画系論文報告集，第 454 号, pp. 197205, 1993. 12

4）鈴木 規道, 積田 洋, 津村 佳余: 河川空間の心理的評価と護岸断 畔柳 昭雄, 渡辺 秀俊 : 都市住民の親水行動特性に関する研究 (その 3$)$ 日本建築学会計画系論文集，第 459 号, pp. 195-203, 1994. 5
客野 尚志, 鳴海 邦碩 : 居住地の水環境に対する行動・認識およびそ の連関に関する研究 日本建築学会計画系論文集, 第 500 号, pp. 169176, 1997. 10

6）村川 三郎，西名 大作：河川環境評価手法に関する研究 その 1 日本 建築学会計画系論文報告集，第 366 号,pp. 42-52, 1986. 8

7）村川三郎, 西名 大作 : 河川環境評価手法に関する研究 その 2 日本建築学会計画系論文報告集，第 384 号, pp. 1-11, 1988.2

8）村川 三郎，西名 大作，村田 浩之：コンピュータ画像処理による河川 環境評価に関する研究 その 1 日本建築学会計画系論文報告集，第 426 号, pp. 45-55, 1991.8

9）西名 大作，村川 三郎：コンピュータ画像処理による河川環境評価 に関する研究 その 2 日本建築学会計画系論文集, 第 494 号, pp. 6169, 1997. 4

10）西名 大作，村川 三郎：コンピュータ画像処理による河川環境整備案 に対する住民意識評価構造の分析 日本建築学会計画系論文報告集，第 441 号, pp. 15-24, 1992. 11

11）門内 輝行 : 街並みの景観に関する記号学的研究 東京大学審査学位論文, 1997

12）船越 徹, 積田 洋, 清水 美佐子 : 参道空間の分節と空間構成要素の 分析 (分節点分析・物理量分析) 参道空間の研究 (その 1) 日本建築学 会計画系論文報告集，第 384 号, pp. 53-62, 1988.2

13）積田 洋 : 都市空間の構成と意識構造の相関に関する研究 東京大学査読学位論文, 1994

14）芦原義信：外部空間の構成／建築から都市一, 彰国社, 1962.4

15）志水英樹 : 街のイメージ構造, 技報堂出版, 1979.5 